\title{
PEMANFAATAN MEDIA SOSIAL INSTAGRAM DALAM AKTIVITAS JURNALISME WARGA DAN IMPLIKASINYA TERHADAP MEDIA KONVENSIONAL
}

\author{
Nadya Valerie Shanaz ${ }^{1}$, Irwansyah ${ }^{2}$ \\ ${ }^{1}$ (Department of Communication Science, Universitas Indonesia), ${ }^{1}$ nadya.valerie01@ui.ac.id \\ 2(Department of Communication Science, Universitas Indonesia),dr.irwansyah.ma@gmail.com
}

\begin{abstract}
In this digital era, the development of new media has given birth to a new form of journalism, namely citizen journalism, where news reporting is not carried out by professional journalists, but ordinary citizens. Various types of new media, especially social media, have opened up opportunities for the general public to be able to participate in the process of delivering information as a source of news to the wider community. The popularity of citizen journalism is growing rapidly, which is marked by the use of citizen journalism content as news products that are broadcast in conventional mass media. Citizen journalism products are able to present information that has escaped the coverage of conventional media journalists, to be disseminated as news products to the public. This article aims to analyze how the use of Instagram social media in supporting citizen journalism activities, as well as the implications of using citizen journalism on conventional media. The research was conducted using qualitative methods with literature study techniques. From the results of the study, it was concluded that conventional mass media was greatly helped by the results of citizen journalism coverage, and currently Instagram social media is the social media most interested in citizens in seeking information related to citizen journalism reporting. However, the development of citizen journalism is not free from problems related to the application of journalistic ethics which is often not carried out, because citizen journalism is carried out by amateurs who do not have a background knowledge in the field of journalism.
\end{abstract}

Key words: Citizen Journalism, Social Media, Instagram, Conventional Mass Media

\begin{abstract}
Abstrak
Di era digital ini, perkembangan media baru telah melahirkan suatu bentuk jurnalisme baru yaitu jurnalisme warga, dimana pelaporan berita tidak dilakukan oleh jurnalis profesional, melainkan warga biasa. Beragam jenis media baru, terutama media sosial, telah membuka kesempatan bagi khalayak umum untuk dapat berpartisipasi dalam proses penyampaian informasi sebagai sumber berita kepada masyarakat luas. Kepopuleran jurnalisme warga semakin berkembang pesat, yang ditandai dengan penggunaan konten jurnalisme warga sebagai produk berita yang ditayangkan di media massa konvensional. Produk jurnalisme warga mampu menyajikan informasi yang luput dari peliputan jurnalis media konvensional, untuk disebarluaskan sebagai produk berita kepada masyarakat. Artikel ini bertujuan untuk menganalisis bagaimana pemanfaatan media sosial instagram dalam mendukung aktivitas jurnalisme warga, serta implikasi pemanfaatan jurnalisme warga terhadap media konvensional. Penelitian dilakukan menggunakan metode kualitatif dengan teknik studi literatur. Dari hasil penelitian disimpulkan bahwa media massa konvensional sangat terbantu oleh hasil peliputan jurnalisme warga, dan saat ini media sosial instagram merupakan media sosial yang paling diminati warga dalam mencari informasi terkait reportase jurnalisme
\end{abstract}


Vol. 3 No.2 10 Juli 2021

DOI : https://doi.org/10.47233/jteksis.v3i2.257

warga. Meski demikian, perkembangan jurnalisme warga tak luput dari problematika terkait penerapan etika jurnalistik yang seringkali tidak dilakukan, sebab jurnalisme warga dilakukan oleh amatir yang tidak memiliki latar belakang pengetahuan di bidang jurnalistik.

Kata kunci: Jurnalisme Warga, Media Sosial, Instagram, Media Massa Konvensional

\section{PENDAHULUAN}

Perkembangan di era digital telah menghadirkan sejumlah tantangan bagi jurnalis dan media massa konvensional yang diakibatkan oleh perkembangan internet dan media baru. Sebelum perkembangan teknologi dan jaringan internet, media massa belum dapat melakukan pembaharuan suatu berita secara cepat maupun real time. Pada media massa seperti radio, surat kabar, maupun televisi misalnya, pemberitaan umumnya baru akan mengalami pembaharuan pada keesokan harinya karena keterbatasan teknologi yang dimiliki untuk mengirimkan informasi. Berbeda dengan saat ini, dimana kecanggihan teknologi telah memungkinkan penyebaran arus informasi secara cepat dan konten pemberitaan pun dapat terus menerus mengalami pembaharuan, dalam hitungan menit bahkan detik. Tak hanya itu, tantangan lain yang harus dihadapi jurnalis dan media konvensional di era digital ini adalah kehadiran beragam bentuk media baru, terutama media sosial. Media sosial, sebagai sebuah platform yang digunakan untuk bersosialisasi melalui teknologi internet. Pengguna media sosial dapat saling berdiskusi, bertukar pikiran dan opini, serta turut berpartisipasi dalam bentuk interaksi sosial kepada sesama pengguna media sosial lainnya. Dalam kaitannya dengan jurnalisme, media sosial kerap digunakan sebagai medium penyebarluasan berita kepada khalayak. Produk berita disajikan melalui konten media sosial menggunakan berbagai fitur yang tersedia di media sosial, seperti diantaranya foto, video, infografis, videografis, hingga muatan konten yang disiarkan secara langsung atau live streaming. Kehadiran media sosial sebagai salah satu bentuk media baru, telah memudahkan adanya proses komunikasi dua arah hubungan antara pengguna serta mendukung terciptanya ruang bagi pengguna untuk berbagi konten (Sundari, 2019). Melalui media sosial pula, muncul peluang yang besar bagi setiap penggunanya untuk memanfaatkan medium tersebut dalam membagikan suatu peristiwa maupun informasi secara real time. Kontribusi yang dilakukan warga melalui media sosial tersebut kemudian menciptakan suatu praktik jurnalisme baru, yang umum dikenal dengan istilah jurnalisme warga. Peristiwa maupun informasi yang disampaikan oleh khalayak umum melalui media sosial ini kemudian dapat diolah dan dimanfaatkan oleh media konvensional menjadi suatu produk berita.

Transformasi jurnalisme di era digital telah menciptakan perkembangan baru dalam teknik peliputan dan reportase di bidang jurnalistik, yang dapat dilakukan oleh warga biasa atau khalayak umum selain jurnalis profesional. Dalam fenomena saat ini, media massa seringkali menyertakan cuplikan rekaman atau hasil reportase suatu peristiwa besar, bencana, maupun kejadian unik yang merupakan hasil kontribusi dari pengguna media sosial. Hasil reportase yang kemudian menjadi suatu produk berita inilah yang kemudian melahirkan istilah citizen journalism atau jurnalisme warga. Karena perkembangan teknologi yang semakin mutakhir, pengguna media sosial dapat dengan mudah berperan sebagai jurnalis warga dengan mempublikasikan informasi maupun peristiwa penting kepada khalayak luas secara cepat. Salah satu produk awal jurnalisme warga di Indonesia yang kemudian memiliki dampak cukup besar pada industri media massa yaitu rekaman video amatir warga pada peristiwa gempa bumi dan tsunami yang melanda kawasan Lamjame, Nanggroe Aceh Darussalam pada 26 Desember 2004 silam. Cut Putri, sang perekam video amatir mengabadikan momen sesaat setelah terjadinya gempa cukup kuat yang kemudian menyebabkan tsunami beberapa menit setelah terjadinya gempa. Dalam video tersebut, terdengar percakapan anggota keluarganya terkait peristiwa gempa yang baru saja terjadi. Hanya selang 
Vol. 3 No.2 10 Juli 2021

DOI : https://doi.org/10.47233/jteksis.v3i2.257

beberapa menit kemudian, rekaman video menunjukkan suasana mencekam dengan latar suara teriakan histeris warga beserta suara gemuruh air. Video amatir detik-detik terjadinya peristiwa tsunami tersebut kemudian disiarkan secara luas melalui stasiun televisi tak hanya di Indonesia saja, namun secara global. Hasil rekaman amatir Cut Putri yang kemudian menjadi produk berita pada media massa mendorong munculnya diskusi mengenai jurnalisme warga.

Allan (2014) mengatakan reportase pada peristiwa bencana alam tsunami Aceh dilakukan oleh warga biasa dengan cara merekam video berisi narasi laporan peristiwa, yang mana hal ini dilakukan layaknya jurnalis media massa. Kehadiran jurnalisme warga pada peristiwa tsunami Aceh dimana mayoritas produk berita dihasilkan dari dokumentasi warga, dikarenakan kesulitan akses bagi jurnalis profesional untuk menjangkau lokasi dan melakukan peliputan. Kerusakan infrastruktur secara masif pada peristiwa tsunami Aceh telah menyebabkan kelumpuhan pada jaringan komunikasi dan akses transportasi yang terputus, sehingga berdampak pada kesulitan peliputan yang dilakukan oleh jurnalis profesional dan menghambat penyampaian informasi kepada khalayak luas. Melihat fenomena tersebut, praktik jurnalisme warga dapat didefinisikan sebagai upaya produksi dan penyebarluasan suatu informasi oleh khalayak umum atau warga biasa. Lebih lanjut, Lasica (2003) mendefinisikan jurnalisme warga sebagai bentuk jurnalisme yang mengakomodir masyarakat umum selain jurnalis profesional untuk dapat menyampaikan informasi atas kejadian atau peristiwa kepada khalayak luas melalui medium tertentu.

Kepopuleran praktik jurnalisme warga terus berkembang terutama dengan kecanggihan di bidang teknologi informasi dan komunikasi yang menyediakan beragam fitur untuk mendukung perkembangan jurnalisme warga. Perkembangan teknologi komunikasi dan informasi telah melahirkan alat seperti smartphone dan laptop, yang dapat digunakan untuk merekam dan mengirim gambar secara mudah, sehingga khalayak umum dapat ikut terlibat dalam proses penyebaran informasi maupun berita. Hanya bermodalkan perangkat

elektronik dan jaringan internet, setiap orang kini dapat menyampaikan hasil reportasenya kepada khalayak dengan mudah. Dengan kecanggihan teknologi, kamera yang dipasangkan pada sejumlah perangkat elektronik memiliki kualitas yang sangat baik dan mampun merekam serta mengabadikan suatu peristiwa secara detail. Sementara untuk mengirimkan hasil reportase maupun dokumentasi tersebut, masyarakat juga dapat melakukannya dengan mudah dan dimana saja, dengan menggunakan perangkat elektronik yang terkoneksi internet.

Perkembangan jurnalisme warga membuat praktik tersebut semakin diminati masyarakat, karena setiap warga kini memiliki kesempatan untuk dapat mengangkat suatu topik maupun isu hangat sebagai produk berita. Tak hanya dinikmati masyarakat umum, Industri media massa juga menjadi salah satu pihak yang memanfaatkan potensi jurnalisme warga dengan cara memproduksi muatan berita melalui konten jurnalisme warga yang dibagikan di media sosial. Dalam hal ini, kehadiran jurnalisme warga tentunya membantu proses kerja di ruang redaksi. Pengambilan konten jurnalisme warga untuk ditayangkan di media massa tentunya mempermudah kerja jurnalis profesional dan memungkinkan perusahaan untuk memproduksi berita dengan biaya yang lebih rendah. Artikel ini berusaha mengkaji pemanfaatan trend jurnalisme warga di media sosial instagram serta implikasi kehadiran jurnalisme warga terhadap industri media konvensional.

\section{KAJIAN PUSTAKA}

\section{Jurnalisme Warga}

Istilah jurnalisme warga secara umum mengacu pada partisipasi aktif masyarakat dalam produksi berita, yang meliputi pengumpulan, pelaporan, analisis, hingga penyajian berita kepada masyarakat luas. Lebih lanjut, Glasser (2006) mendefinisikan jurnalisme warga sebagai aktivitas jurnalistik yang dilakukan oleh khalayak umum tanpa pengetahuan dan sertifikasi di bidang jurnalisme dengan memanfaatkan teknologi modern dan jaringan internet dalam upaya untuk membuat serta mendistribusikan hasil peliputannya secara luas. Kehadiran 
Vol. 3 No.2 10 Juli 2021

DOI : https://doi.org/10.47233/jteksis.v3i2.257

jurnalisme warga muncul akibat kebutuhan informasi masyarakat yang tinggi, dan hal ini tidak sepenuhnya dapat diperoleh melalui media konvensional saja. Jurnalisme warga memiliki sejumlah metode dalam penyebaran informasi, namun hal yang paling umum dijumpai saat ini adalah dengan menggunakan teknologi baru industri komunikasi dan informasi, seperti internet, perangkat elektronik, kamera digital, dll. Setiap orang dapat berkontribusi dalam penyajian informasi maupun berita, meski tidak memiliki latar belakang di bidang jurnalistik. Aktivitas jurnalisme warga dapat dilakukan kapanpun, dimanapun, dan oleh siapapun dengan didukung oleh perangkat digital serta jaringan internet. Hal ini membuat tren jurnalisme warga semakin berkembang, dan hasil peliputan dari jurnalis warga pun dimanfaatkan oleh perusahaan media massa konvensional. Dalam perkembangannya, jurnalisme warga memiliki manfaat di bidang industri media konvensional, yakni untuk mengisi kekosongan maupun hal yang luput dari pemberitaan jurnalis media konvensional. Aktivitas jurnalisme warga mampu mengabadikan suatu kejadian maupun momen penting, yang terabaikan dari peliputan jurnalis media konvensional.

\section{Media Sosial Instagram}

Perkembangan jurnalisme warga di media sosial tak lepas dari kehadiran media yang memfasilitasi penggunanya untuk memproduksi konten secara mandiri atau yang dikenal sebagai user generated content. Instagram salah satunya, merupakan platform media sosial yang memfasilitasi user generated content bagi penggunanya. Nama instagram merupakan gabungan dari dua kata yaitu "insta" yang berarti mudah, dan "gram" yang diartikan sebagai medium pengiriman informasi yang sangat cepat. Artinya, aplikasi instagram dibuat sebagai media untuk mengabadikan momen dalam bentuk foto maupun video dan membagikannya dengan sangat cepat. Meski terbilang baru, namun instagram berhasil meraih kepopuleran dengan cukup cepat dan menjadi salah satu jejaring media sosial yang paling banyak digunakan masyarakat digital di Indonesia. Melalui fiturfitur menarik yang fokus terhadap penyajian konten audio visual, instagram saat ini banyak

dimanfaatkan sebagai wadah publikasi jurnalisme warga. Fenomena perkembangan jurnalisme warga di instagram berawal dari maraknya pemanfaatan akun instagram yang dikhususkan untuk menyajikan muatan berita dari hasil reportase warga biasa. Umumnya akun tersebut menampilkan sejumlah konten baik berupa foto maupun video beserta narasi terkait suatu peristiwa yang telah diunggah oleh pemilik akun media sosial lainnya. Akun-akun tersebut kemudian menjadi populer karena kecepatannya dalam menyebarluaskan reportase terkait suatu kejadian maupun peristiwa dan memiliki jumlah followers ataupun akun pengikut dengan jumlah yang tinggi.

\section{Pemanfaatan Jurnalisme Warga oleh Media Konvensional}

Media massa merupakan instrumen penting dalam pemenuhan kebutuhan informasi masyarakat. Sebelum perkembangan teknologi digital dan internet, media massa memiliki beberapa bentuk, diantaranya surat kabar, radio, serta televisi. Faktor utama yang membedakan media massa konvensional dengan media baru, adalah penggunaan teknologi informasi dan komunikasi yang lebih mutakhir, salah satunya internet. Dewasa ini, media massa di era digital telah mengalami transformasi bentuk, seperti adanya koran digital, televisi yang disiarkan melalui jaringan internet, serta media online. Hal tersebut lah yang menjadi pembeda antara media massa yang bersifat konvensional dengan media baru. Di Indonesia, eksistensi media massa konvensional masih bertahan meski harus beradaptasi dengan perkembangan di era digital. Contohnya, sejumlah perusahaan media cetak maupun elektronik, memperluas usaha media nya ke bentuk media baru. Salah satu strategi adaptasi yang dilakukan media massa konvensional adalah penerapan aktivitas jurnalistik secara online ke dalam unsur pemberitaannya. Dalam hal ini, perusahaan media kerap menayangkan dokumentasi berupa foto maupun video yang diunggah ke media sosial, untuk ditayangkan sebagai konten berita. Hal tersebut tentunya memiliki manfaat, sebab karena keterbatasan waktu dan sumber daya, tak semua peristiwa penting dapat diliput jurnalis. Pemanfaatan hasil reportase jurnalis amatir melalui media sosial 
Vol. 3 No.2 10 Juli 2021

DOI : https://doi.org/10.47233/jteksis.v3i2.257

juga menguntungkan perusahaan media konvensional, karena biaya produksi yang dikeluarkan menjadi minim.

\section{METODE PENELITIAN}

\section{Penelitian ini dilakukan dengan} menggunakan pendekatan kualitatif melalui teknik studi literatur. Pengumpulan data diperoleh dari hasil studi terdahulu pada topik jurnalisme warga serta dokumen-dokumen terkait praktik jurnalisme warga pada media sosial instagram. Peneliti mengumpulkan beberapa artikel yang mengangkat tema jurnalisme warga dan mengambil sejumlah konten berita hasil produksi jurnalisme warga yang diunggah melalui media sosial instagram. Data yang telah diperoleh kemudian dianalisis menggunakan teknik literature review atau kajian literatur. Metode kajian literatur digunakan peneliti agar sejumlah dokumen pustaka terkait tema penelitian dapat dikaji secara sistematis dengan tujuan untuk mensintesis informasi penting yang dapat disimpulkan. Kajian literatur bertujuan untuk menggambarkan metode penelitian dari studi terdahulu, mengumpulkan data dan informasi penting, serta melakukan analisis terhadap data yang telah diperoleh. Penulis terlebih dahulu mengumpulkan penelitian dan studi terkait jurnalisme warga di Indonesia, metode penelitian yang digunakan dan teknik pengumpulan data, untuk kemudian dianalisis dan diperoleh sintesis terkait perkembangan tren jurnalisme warga di Indonesia.

\section{PEMBAHASAN}

Jurnalisme warga saat ini menjadi alternatif bagi publik untuk dapat berkontribusi dalam menyajikan informasi hangat serta peristiwa penting, yang luput dari pemberitaan di media konvensional. Dalam perkembangannya, aktivitas jurnalisme warga sangat terbantu dengan kecanggihan teknologi media baru, terutama media sosial instagram. Kecanggihan fitur yang terdapat pada media sosial instagram mampu mengakomodir aktivitas jurnalisme warga melalui fitur pengunggahan foto dan video, menghadirkan interaksi dua arah antar pengguna, serta memungkinkan pengguna media sosial untuk menyimpan serta membagikan unggahan tersebut kepada pengguna lainnya. Melalui aktivitas jurnalisme warga di media sosial, masyarakat dapat mengakses konten informasi serta membahas sejumlah hal maupun peristiwa 'hangat' yang tengah terjadi. Secara umum, jurnalisme warga di media sosial tak hanya berfungsi sebagai sumber informasi bagi penggunanya, namun juga bersifat heterogen karena memungkinkan adanya pertukaran informasi antar pengguna (Romli, 2012). Aktivitas jurnalisme warga juga memberikan sejumlah manfaat bagi masyarakat luas, seperti halnya pada peristiwa Tsunami di Aceh pada 2004 silam, informasi yang disediakan melalui video amatir warga menjadi dokumentasi primer awal mula kejadian tersebut, dan kecepatan penyebaran informasi kemudian membuat hasil reportase warga dapat dilihat oleh dunia internasional, sehingga mempercepat datangnya bantuan dari negara-negara tetangga. Hal ini merupakan salah satu kelebihan utama dari jurnalisme warga, yakni kemampuan untuk dapat menyebarkan informasi secara cepat dan luas. Jurnalis warga juga seringkali merupakan orang pertama yang mendapatkan akses untuk meliput suatu peristiwa penting, seperti bencana alam, kecelakaan, serta fenomena unik, yang tidak seluruhnya dapat diliput jurnalis. Oleh sebab itu, saat ini media konvensional telah memanfaatkan hasil reportase dari para jurnalis warga, karena nilai berita atau news value yang tinggi. Selain dari segi news value, aktivitas jurnalisme warga juga menguntungkan perusahaan media dalam pengeluaran biaya produksi, sebab konten yang dibagikan oleh jurnalis warga di media sosial bersifat gratis. Perusahaan media cukup mencantumkan sumber asal dari hasil dokumentasi tersebut, tanpa perlu membayar si penyebar konten.

Bagi perusahaan media konvensional, hasil reportase jurnalis warga dapat melengkapi produk berita yang ingin ditayangkan. Misalnya saja dalam peristiwa kebakaran yang tentunya terjadi secara tiba-tiba, tidak mungkin jurnalis telah ditugaskan di lokasi tersebut sebelum peristiwa kebakaran terjadi. Jurnalis baru mendapatkan penugasan ke lokasi kejadian, saat informasi terjadinya peristiwa kebakaran sudah tersebar. Meski demikian, seringkali di lapangan 
Vol. 3 No.2 10 Juli 2021

DOI : https://doi.org/10.47233/jteksis.v3i2.257

jurnalis menemui sejumlah kendala, seperti lokasi yang jauh atau sulit mendapatkan akses ke lokasi, sehingga terlambat untuk mengabadikan momen penting dari suatu peristiwa. Disinilah jurnalis warga memegang peran penting, melalui video amatir, dokumentasi tersebut dapat digunakan oleh perusahaan media untuk melengkapi kebutuhan visual. Tak hanya peristiwa seperti kecelakaan dan bencana alam, namun jurnalis warga juga dapat memberitakan suatu kejadian maupun pelanggaran hukum yang meresahkan publik. Sudah berulang kali hasil reportase jurnalis warga menjadi 'bekal' bagi aparat penegak hukum, untuk mengusut suatu kasus pelanggaran hukum oleh warga. Contohnya saja, aksi koboi jalanan yang dilakukan seorang warga di daerah Duren Sawit, Jakarta Timur, yang menodongkan senjata api kepada pengendara kendaraan bermotor. Melalui video amatir yang direkam warga di lokasi kejadian, polisi kemudian dapat mengidentifikasi pelaku melalui tangkapan layar plat kendaraan serta wajah pelaku yang terekam di video tersebut. Kemudian sejumlah aksi lainnya seperti kekerasan, penghinaan, dan pelanggaran lainnya pun sudah banyak terungkap berkat aktivitas jurnalisme warga.

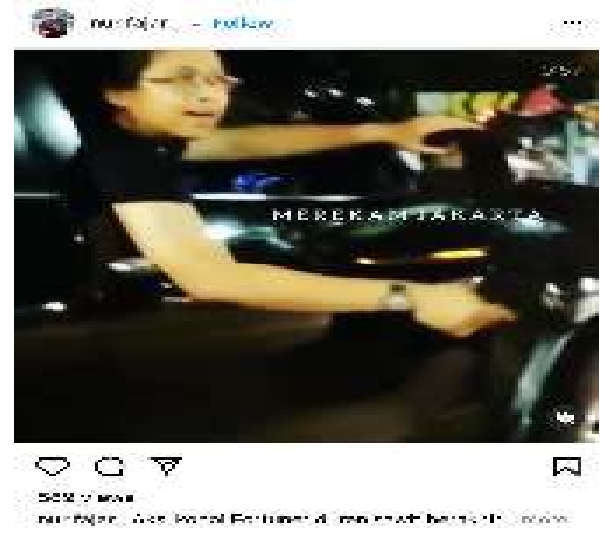

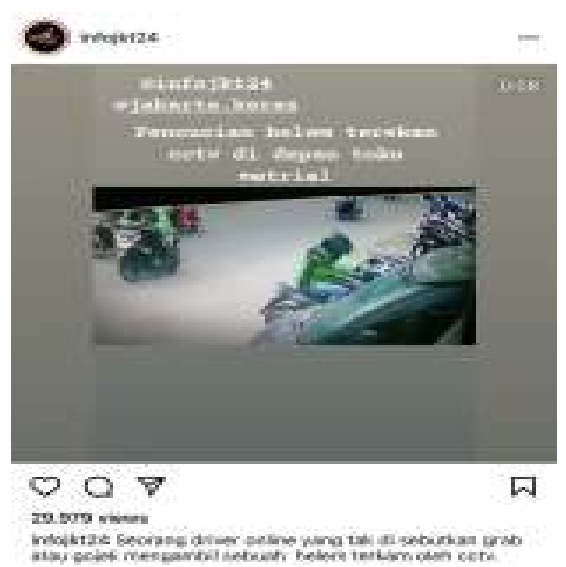

1.1 Hasil reportase jurnalis warga di media sosial instagram

Meski sejauh ini, sejumlah literatur menyebutkan pemanfaatan jurnalisme warga yang menguntungkan perusahaan media konvensional, namun nyatanya perkembangan jurnalisme warga juga memiliki beberapa tantangan. Tantangan utama yang ditemui pada perkembangan aktivitas jurnalisme warga yaitu fakta bahwa jurnalis warga merupakan masyarakat biasa, yang tidak memiliki keahlian dan pelatihan di bidang jurnalistik. Karena merupakan warga biasa, mereka tidak memiliki pengetahuan di bidang pengelolaan dan produksi berita, sehingga seringkali konten yang dihasilkan dapat melanggar kaidah jurnalistik. Misalnya saja, jurnalis warga dapat menyebarkan foto ataupun video dari pelaku maupun korban yang masih berusia di bawah umur, serta tayangan yang mengandung muatan kekerasan. Sementara, hal tersebut umumnya tidak dijumpai dalam produk berita yang merupakan hasil reportase dari jurnalis profesional, karena adanya kode etik yang harus dipatuhi. Selain itu, jurnalis profesional dalam memproduksi berita terikat oleh sistem di instansi tempatnya bekerja, serta terikat oleh hukum dari profesinya sebagai wartawan. Jurnalis tidak boleh semaunya dalam melakukan reportase dan menyajikan informasi kepada publik. Produk berita yang dihasilkan jurnalis profesional juga harus memenuhi sejumlah unsur, diantaranya penyajian informasi yang akurat dan sesuai fakta, narasumber yang relevan, dan pemberitaan yang bersifat meliputi dua sisi atau cover both sides. Sementara itu, jurnalis warga merupakan orang biasa yang 
Vol. 3 No.2 10 Juli 2021

DOI : https://doi.org/10.47233/jteksis.v3i2.257

dalam menyebarluaskan informasi dapat berlaku semaunya, dan hasil dokumentasinya tidak selalu didasarkan pada kaidah jurnalistik.

\section{KESIMPULAN}

\section{Berdasarkan hasil kajian literatur,} penulis menyimpulkan bahwa media konvensional mendapatkan sejumlah manfaat dari aktivitas jurnalisme warga, dalam hal penggunaan konten berita yang memiliki news value tinggi serta menekan biaya produksi berita. Kepopuleran jurnalisme warga mengalami perkembangan pesat dengan pemanfaatan fitur media sosial, terutama instagram, yang merupakan salah satu sumber informasi paling diminati masyarakat saat ini. Kecanggihan teknologi mutakhir telah memungkinkan bagi setiap warga tanpa terkecuali, untuk turut berkontribusi dalam pengolahan dan produksi berita, serta menyebarluaskannya secara masif. Setiap warga, dimanapun dan kapanpun dapat melaporkan suatu kejadian maupun peristiwa secara cepat maupun real time, hanya dengan bermodalkan perangkat elektronik yang terkoneksi internet. Hubungan antara jurnalis warga dan industri media konvensional dapat dikatakan saling menguntungkan ataupun memiliki simbiosis mutualisme. Meski demikian, tak dapat dipungkiri bahwa kehadiran jurnalis warga memiliki sejumlah tantangan, diantaranya muatan informasi yang dihasilkan tak selalu sesuai dengan kaidah jurnalistik dan penerapan kode etik. Kualitas berita yang merupakan hasil reportase jurnalis warga masih perlu diperhatikan, agar tidak membawa dampak buruk bagi audiensnya.

\section{DAFTAR PUSTAKA}

Arif Swa. 2010. Pertarungan Citizen Journalism. Kompasiana.

Bowman, Shane \& Willis, Chris. 2003. We Media: How Audience are Shaping the Future of News and Information. The Media Center at the American Press Institute

Didit Adiputro. 2009. Citizen Journalism Wujud Dari Demokrasi Total. Jakarta.Perspektif Online.
Dirgahayu, Dida. 2007. Citizen Journalism Sebagai Ruang Publik. Majalah Observasi. Vol 5. No.1, pp. 11-31

Hartawan Yusuf. 2017. Media Sosial Sebagai Media Massa Dikalangan Remaja. Jurnal Retorika Vol. 9. Bandung : Universitas Pasundan.

Howard. 2006. New Media Campaigns and the Managed Citizen. Cambridge: Cambridge University Press.

Kovach, Bill., Tom Rosenstiel. 2003. Sembilan Elemen Jurnalisme, Apa yang Seharusnya Diketahui Wartawan dan yang Diharapkan Publik. Jakarta: Yayasan Pantau, Institut Studi Arus Informasi dan Kedutaan Besar Amerika Serikat

Rizki Hermadinata Mochammad. 2016. Citizen Journalism sebagai Bentuk Jurnalistik Modern (Studi Fenomenologi Citizen Journalism di Kanal Net Citizen Journalist). Skripsi.Bandung:Universitas Pasundan.

Romli, A. S. (2012). Jurnalistik Online (Panduan Praktis Mengelola Media Online). Bandung: Nuansa Cendekia.

Sukartik Dewi. 2016. Peran Jurnalisme Warga dalam Mengakomodir Aspirasi Masyarakat. Jurnal Dakwah Risalah Vol. 27 No.1. Riau: Universitas Islam negeri Sultan Syarifudin.

Yudhapramesti, Pandan. 2007. Citizen Journalism (CJ) Sebagai Media Pemberdayaan Warga. Majalah Observasi. Vol 5. no. 1, pp. 3345 